\title{
The representation of curricular spider-web model in the Lesotho curriculum and assessment policy framework
}

\begin{tabular}{|c|c|}
\hline \multicolumn{2}{|c|}{$\begin{array}{l}\text { Authors: } \\
\text { Makhulu A. Makumane }{ }^{1} \\
\text { Sandiso } \text { Ngcobo }^{2}\end{array}$} \\
\hline \multicolumn{2}{|c|}{$\begin{array}{l}\text { Affiliations: } \\
\text { 'Department of Languages } \\
\text { and Social Education, } \\
\text { Faculty Education, National } \\
\text { University of Lesotho, Roma, } \\
\text { Lesotho }\end{array}$} \\
\hline \multicolumn{2}{|c|}{$\begin{array}{l}{ }^{2} \text { Department of } \\
\text { Communication, Faculty } \\
\text { of Management Sciences, } \\
\text { Mangosuthu University } \\
\text { of Technology, Durban, } \\
\text { South Africa }\end{array}$} \\
\hline \multicolumn{2}{|c|}{$\begin{array}{l}\text { Corresponding author: } \\
\text { Sandiso Ngcobo, } \\
\text { sandiso@ @ut.ac.za }\end{array}$} \\
\hline \multicolumn{2}{|c|}{$\begin{array}{l}\text { Received: } 04 \text { Dec. } 2019 \\
\text { Accepted: } 28 \text { Oct. } 2020 \\
\text { Published: } 24 \text { Mar. } 2021\end{array}$} \\
\hline \multicolumn{2}{|c|}{$\begin{array}{l}\text { How to cite this article: } \\
\text { Makumane MA, Ngcobo S. } \\
\text { The representation of } \\
\text { curricular spider-web model } \\
\text { in the Lesotho curriculum } \\
\text { and assessment policy } \\
\text { framework. J transdiscipl res } \\
\text { S Afr. } 2021 ; 17(1), \text { a796. } \\
\text { https://doi.org/10.4102/ } \\
\text { td.v17i1.796 }\end{array}$} \\
\hline \multicolumn{2}{|c|}{$\begin{array}{l}\text { Copyright: } \\
\text { (c) 2021. The Authors. } \\
\text { Licensee: AOSIS. This } \\
\text { licensed under the } \\
\text { Creative Commons } \\
\text { Attribution License. }\end{array}$} \\
\hline \multicolumn{2}{|l|}{ Read online: } \\
\hline 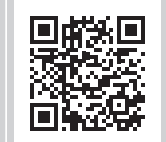 & $\begin{array}{l}\text { Scan this QR } \\
\text { code with your } \\
\text { smart phone or } \\
\text { mobile device } \\
\text { to read online. }\end{array}$ \\
\hline
\end{tabular}

Over the years, curriculum reforms have formed part of Lesotho's attempt to address the socio-economic development factor through education policies such as the Lesotho curriculum and assessment policy (CAP) framework, introduced in 2009. This framework is meant to guide curriculum development and design processes. Through content analysis, this article seeks to highlight the representation of the curricular spider-web model's concepts, which guide effective curriculum development, in the policy framework. Curriculum and assessment policy framework and the guide to continuous assessment document, which is a counteractive document that acts as an amendment of the 2009 policy, were analysed using the guided analysis method. Findings suggest that there are some concepts, which are neglected by the framework. This may have a negative bearing on the curriculum development process. This article draws from the curricular spider-web to recommend a review of the CAP framework towards inclusion and alignment of omitted concepts for the facilitation of an effective curriculum design process.

Keywords: Lesotho; CAP; curriculum development; policy; spider web.

\section{Introduction}

Education plays a vital role in the advancement of Lesotho's socio-economic development and national development. ${ }^{1}$ Amongst other efforts, the GoL has integrated French into the secondary school curriculum with the hope that it will assist towards enhancing the inconsistent economy, promote personal growth and national development. ${ }^{2}$ This effort appears to have been embraced by a promising number of learners. ${ }^{2}$

However, over the years, different curricula have been introduced, although with little success, in response to personal (habitual), social and professional needs of the society and of the country as a whole. ${ }^{3}$ Spaull ${ }^{4}$ described such a situation as an indication of a dysfunctional education system in which learner's academic achievement would tend to be inconsistent with national curriculum standards and international assessments. Similarly, the dismal attempts in curriculum development in Lesotho appeared to be a result of an apparent misalignment between curriculum and assessment. However, Molapo and Pillay ${ }^{5}$ acknowledged that curriculum change is a global challenge that, therefore, requires creative solutions.

In an effort to salvage the situation, Lesotho government introduced the curriculum and assessment policy (CAP) framework in 2009 in view of achieving educational goals for national development. According to Raselimo and Mahao, ${ }^{3}:$ p.1 the 2009 CAP was initiated 'as a strategy to minimise the negative influence of examinations on the education system by integrating curriculum with assessment' in order to curb concerns pertaining to the alignment of school and public examination. The main aim of this education policy is to guarantee access, quality, equity and relevance, that is, facilitated through education (Ministry of Education and Training, hereafter MOET). ${ }^{6}$ In addition, the policy is meant to amalgamate societal problems with the overall developmental goals of the country. Such problems, which include the rampant spread of HIV, high unemployment rate, high poverty and environmental degradation, seemed to pose a threat to the socio-economic development of Lesotho. ${ }^{3}$ Thus, to deal with these seemingly imminent threats to sustainable development, the 2009 CAP was introduced, where knowledge was seen to be derived from 'pressing' societal issues to promote local knowledge, as well as school knowledge, where global trends, through prescribed content are included in view of embracing the concept of globalisation. ${ }^{7}$ In other 
words, both local knowledge and school knowledge were seen as imperative in ensuring quality and relevance in the education sector. ${ }^{3}$ In essence, the education policy, through its adaptation of the integrated curriculum and its advocacy of using the learner-centred approach, supports lifelong learning, production and work-related competencies. ${ }^{6}$ The framework is intended to guide the process of curriculum design and development in line with the introduction of the concept of an integrated curriculum, which includes vocational and life skills orientation programmes in mainstream schools. ${ }^{6}$ Notably, this policy framework premises a significant reform in the form of a shift from an examination-oriented education system to a more process-oriented system that integrates teaching and learning with assessment for a more effective curriculum. ${ }^{3}$ Lesotho's introduction of the CAP framework is in line with the view expressed by Brasof and Mansfield ${ }^{8}$ on the importance of governments to address challenges with their education systems if they are to uplift the standard of their children's education and compete globally.

Therefore, the success of the CAP framework can be examined against whether it addresses all the pertinent curriculum concepts, and thus, conforms to the internationally recognised curriculum spider-web model. It is in this sense that the article critically analyses content presented in the CAP framework in order to identify the representation of Van den Akker's ${ }^{9}$ curricular spider-web model. This model, with its provision of guiding questions (see Figure 1), is deemed to be instrumental in steering effective curriculum development. An effective curriculum design is expected to contribute to developing the targeted learning outcomes. ${ }^{10}$ In the case of Lesotho, this would mean that the CAP should be able to achieve educational goals for national development.

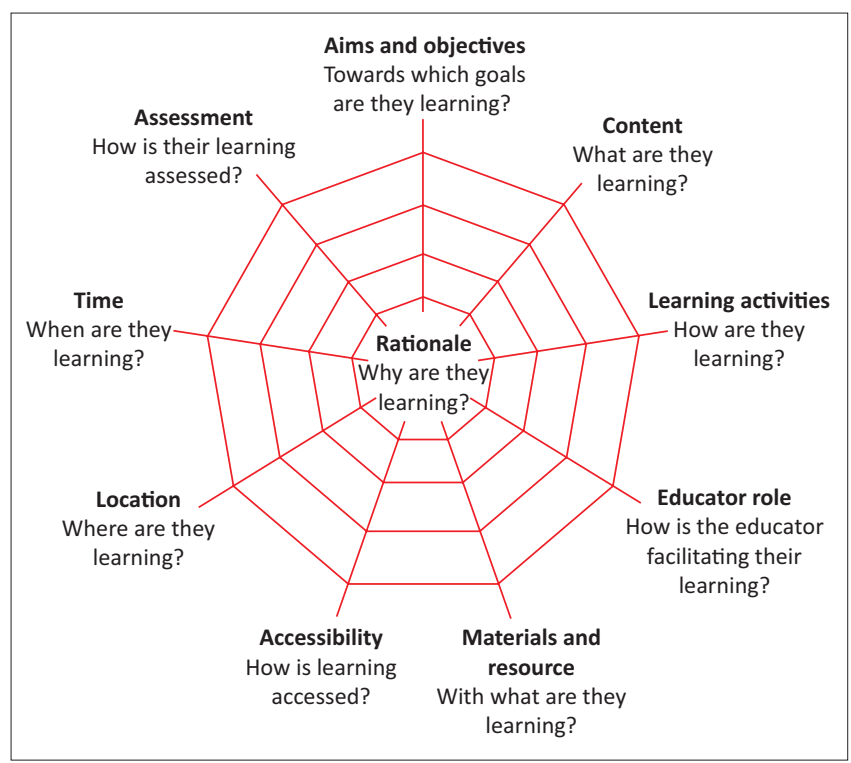

Source: Van den Akker, J., 2003, 'Curriculum perspectives: An introduction', in J. Van den Akker, W. Kuiper \& U. Hameyer (eds.), Curriculum landscapes and trends, pp. 1-10, Kluwe Academic Publishers, Dordrecht.

FIGURE 1: Curricular spider web.
Available research appears to have focussed mostly on the alignment of textbooks with CAP's framework. For example, Ngwenya and Arek-Bawa ${ }^{11}$ adopted the qualitative content analysis (QCA) approach to investigate the quality of two Grade 12 accounting textbooks in South Africa in respect to content, structure and organisation, guidance and support and assessment tasks. In contrast, this article addresses the gap in research that explores the alignment of the curriculum to CAP framework in the Lesotho context. The purpose of this evaluation is, therefore, to determine if there is consistency between curriculum and practice.

Thus, as one of Lesotho's CAP's main aims is to guide the curriculum development process, as such, the adopted model proved fitting to determine whether essential curriculum concepts are captured in the CAP framework, as negligence thereof has proven to have adverse outcomes, especially during curriculum enactment. Aligned with the aim of this article, which is to scrutinise the representation of the curricular spider web and teaching and learning signals in the policy framework, an attempt is made to answer the following question: What is the representation of the curricular spider-web model in the CAP? It is hoped that addressing this question might sensitise policymakers to factors that contribute to effective curriculum development and thus initiate a policy framework that subscribes to the curricular spiderweb model.

\section{Conceptual framework: Curricular spider-web model}

The concept of curricular spider-web model was introduced by Van den Akker ${ }^{9}$ in view of clarifying the importance of the relationship between curriculum concepts that form the core of the curriculum. As the curriculum is seen as a plan for teaching, ${ }^{12}$ there exists a framework of concepts that tackle specific questions that guide curriculum development. ${ }^{13}$ This framework is known as the curricular spider web. It comprises 10 concepts that are interlinked and thus affects each other. This denotes that a change in one concept during curriculum development results in a domino effect that affects other concepts. ${ }^{14}$ This assertion suggests that the spider web highlights the importance of each curriculum concept in contributing to a successful curriculum that addresses educational needs. Van den Akker et al. ${ }^{15}$ asserted that 'the spider web thus illustrates a familiar expression; every chain is as strong as its weakest link'. This contention implies that should there be a concept that is neglected during the process of curriculum development, the curriculum is likely to be compromised. The spider web thus demonstrates the susceptibility of the curriculum and how the alignment of its concepts is essential to ensuring attainment of goals stipulated in the policy framework and in the intended curriculum. Figure 1 illustrates the curricular spider web as adapted from Van den Akker. ${ }^{9}$ 
As Figure 1 shows, there are 10 concepts in the curricular spider web. Rationale, as defined by Van den Akker et al., ${ }^{13}$ alludes to universal principles or reasoning of a plan to be executed. This concept deals with the 'why' question, that is, why the curriculum is being conceived, which then translates into the vision, as devised by policymakers. ${ }^{16}$ However, as Mpungose ${ }^{17}$ posited, policymakers should establish the 'why' of teaching a subject (rationale) before curriculum development in order to help developers understand the essentiality of that particular subject/ discipline. Furthermore, Berkvens et al. ${ }^{14}$ think that rationale is influenced by three propositions: personal (habitual representation), social (social representation) and professional (factual representation). In essence, policymakers need to take into consideration these three propositions at the macro (national) level whilst devising a policy in order to guide the micro (educator) level of curriculum design. This article is, therefore, based on the assumption that policymakers are influenced by their habitual representation in determining both the social and factual representation. This suggests that they take into consideration the need for a policy to contribute towards the immediate needs of the society and towards the application of the cognitive domain by learners. ${ }^{18}$

As the curriculum is designed for learners, there are vital core questions that curriculum developers/designers need to use as a guide during the development process. ${ }^{14}$ These are: Why are they learning? (Rationale); Towards which goals are they learning? (Aims and objectives); What are they learning? (Content); How are they learning? (Learning activities); How is the educator facilitating their learning? (Educator role); With what are they learning? (Materials and resources); How is learning accessed? (Accessibility); Where are they learning? (Location); When are they learning? (Time) and How is their learning assessed? (Assessment). Addressing these questions during curriculum development favours effective enactment of the curriculum. ${ }^{9}$

\section{Research design and methodology}

This article uses the QCA research method to systematically and objectively describe and broadly quantify the phenomenon in the text in question. ${ }^{19,20}$ Qualitative content analysis was considered as suitable for this study as it (the study) is aimed at examining the representation of the curricular spider-web concepts in the CAP framework (text) in order to study the implications thereof for effective curriculum development/design process. Hence, the method used for data generation was document analysis, where the CAP framework was used. Punch ${ }^{21}$ argued for the use of documents in data generation as they are often rich in data. Document analysis is, however, sometimes presented with a problem of incompleteness, where documents being analysed might have gaps that cannot be filled. ${ }^{22}$ To overcome this challenge, the guide to continuous assessment (CASS) document, which is a counteractive document that acts as an amendment of the 2009 policy, was also analysed. These two documents helped to establish whether the curricular spider-web signals were represented therein to effectively guide the curriculum development/design processes.

The data analysis method used for this study was guided analysis. ${ }^{23}$ This method, as described by Samuel ${ }^{23}$, involves determining categories before the generation of data and having to modify the categories as per interaction with data at the analysis stage. Thus, the categories that were developed a priori (Samuel ${ }^{23}$ ) are negotiated and refined in the light of accommodating generated data. ${ }^{16}$ This method of analysis fitted for this study as it was possible for categories to surface that were not initially envisaged. The categories in this study were informed by the curricular spider-web concepts, thus, sections that were meant to address these concepts were sampled.

\section{Ethical consideration}

The study involved content analysis which required that the researchers take into account applicable ethical issues by avoiding bias, assumptions and theoretical orientations from interfering with the findings.

\section{Findings and discussion Analysis of curriculum and assessment policy framework in relation to the curricular spider web and/or signals}

The analysis is presented in categories in view of clearly highlighting the representation, or lack thereof, of each curricular spider-web concept and/or signal.

\section{Category 1: Assessment}

Assessment should evaluate the attainment of educational and curriculum aims of educational programmes at all levels. Thus there is need to broaden the modes of assessment to include the following: Formative assessment, which comprises both diagnostic and continuous assessment, monitoring of educational progress through a national educational assessment carried out at regular intervals; and summative assessment (which usually tests mostly cognitive domain) for selection and certification purposes (p. viii). ${ }^{6}$

From the given quotation from the policy framework, as far as assessment is concerned, habitual representation and factual representation are recommended to diagnose learners' current knowledge for improvement and further learning (formative assessment) and to evaluate the learners' cognitive domain for promotion and certification purposes (summative assessment). ${ }^{6}$ Notably, however, the policy framework makes no mention of peer assessment. It does consequently mention the use of CASS that, as the name suggests, is an on-going assessment process that helps to improve learning (Examinations Council of Lesotho, thereafter ECOL). ${ }^{24}$ Nevertheless, CASS is somewhat married to formative assessment in the policy framework, which might be 
misleading to curriculum developers in the sense that it might be mistaken for an educator-centred form of assessment (assessment for testing in place of assessment for learning). Exclusion of peer assessment in the policy framework implies that curriculum developers and designers possibly neglect social representation that takes into consideration learners' views during the assessment process.

In an attempt to remedy an oversight of leaving out peer assessment strategy, the ECOL devised a counteractive document in 2012 to provide a guide in using CASS. The document acts as an amendment of the policy and recommends peer assessment as a way of 'making sure that learners help each other and deepen their own learning' ( $p$. $30)^{24}$ and as a strategy for time preservation. Although peer assessment is recommended, the ECOL cautions curriculum designers not to favour it as the only means of assessment as learners still entrust educators with the role of being assessors. This suggests that the document recommends that educators take charge of the assessment process and should thus limit learner involvement, although not totally discard it as a form of assessment. Thus, both documents, albeit with different potency, favour the use of factual and habitual representations, seemingly neglecting or downplaying the effectiveness of social representation as far as assessment is concerned. This assessment approach appears to go against the view that favours the utilisation of more traditionally structured and didactic modes and experiential and inquirybased modes in designing a curriculum that can fully develop all of the desired learning outcomes. ${ }^{10}$

\section{Category 2: Teaching activities}

Learners are to become more responsible for their own learning processes and thus should be able to identify, formulate and solve problems by themselves and evaluate their work. Hence teaching methods which are learner-centred based more on learners' own activities (p. 22). ${ }^{6}$

Teaching activities are termed as pedagogy in the policy document. The given quote suggests that problem-centred activities should be prioritised as they allow for consideration of the needs and interests of the learner. ${ }^{25}$ Problem-centred activities favour active participation of the learner in knowledge construction, which enables learners to participate and interact to simulate life-like situations. Therefore, learners need to be exposed to skills that would enable them to participate and function in their society. ${ }^{6}$ Thus, the policy advocates for social representation, as it recommends for a pedagogical paradigm that addresses the needs and interests of the learners and consequently speaks to the concept of the integrated curriculum.

In addition, the framework is cognisant of the fact that learners also need to be exposed to the professional and/or global world: ${ }^{6}$

Curriculum should therefore promote the creation, acquisition and utilisation of knowledge and skills as well as development of attitudes and values necessary for participation in advancing personal and socio-economic development and participation in globalisation. (p. 14)

This assertion denotes that the policy considers factual knowledge to be of great importance to the growth of the learner. Consequently, in addition to local and contextualised activities, curriculum developers are advised to propose activities that would make learners aware of the global world through technological and/or entrepreneurial activities. ${ }^{6}$ Accordingly, there exists factual representation in terms of teaching activities.

Furthermore, the policy advocates for 'increased awareness and participation in democratic processes and promotion of human rights, peace, stability and prosperity ...' (p. 14). ${ }^{6}$ This citation mirrors Freire's political pedagogy theory, which strives to emancipate the oppressed from a false view of knowledge and to give them a voice in taking responsibility to form opinions that would shape their independent lifestyles. ${ }^{26}$ Complementing this view is Moloi' ${ }^{27}$ argument for the use of critical pedagogy as a method of teaching for learner engagement in curriculum development and decision-making because of its capacity to enable stakeholders to challenge and struggle against any form of social oppression that dehumanises and renders them failures. This appears to indicate that the policy equally addresses individual growth, thus signifying habitual representation in terms of teaching activities.

\section{Category 3: Content}

Sharma et al. ${ }^{28}$ asserted that the intertwined nature of content and context requires that educators involved in curriculum organisation may need to create lesson plans and syllabi within the framework of the given curriculum to meet the needs of the learners. In the same breath, the policy framework suggests that content be contextualised to address local needs ${ }^{3,6}$

[T]raditional school subjects within the current school system do not adequately address most of [the social] problems and challenges. Hence they have to be refocused by placing them within the social context. (p. 15)

Cross, Mungadi and Rouhani ${ }^{29}$ posited that such a policy reform encourages local and community participation and relevant stakeholders in order to incorporate societal needs in the education system. This assertion alludes to Stenhouse' $\mathrm{s}^{30}$ theory of curriculum development, which advocates for community involvement in curriculum design to address the needs of the society whilst also empowering that particular society through its learners. Nembhard's ${ }^{31}$ study found that educators welcomed the flexible curriculum, which allowed them and learners more opportunities to interrogate the topic content and address issues of social justice. This understanding has also been found to exist amongst publishers of accounting textbooks in South Africa. The publishers were found to have produced textbooks that were aligned with the curriculum requirements in terms of both 
the content and its connections with real-life situations, which contributed to a better understanding of content. ${ }^{11}$

The Lesotho policy on education proposed an interdisciplinary curriculum, which disposes of subject boundaries and addresses issues related to intelligence, maturity, personal and social development of the learner for survival purposes ...' (p. 15). ${ }^{6}$ This implies that content is taken from everyday knowledge (horizontal curriculum) and is thus context-dependent. ${ }^{32}$ The policy, therefore, recommends that critical issues such as the high unemployment rate, endemic poverty, rampant spread of HIV and AIDS, gender inequality and inequity and threats to democracy, should form part of the content in view that learners are equipped with knowledge, attitudes, values and skills to solve them. ${ }^{6}$ This denotes that curriculum developers have to take into consideration societal needs, therefore, invoking social representation.

The above assertions highlight yet another contradiction inferred from the policy. Explicitly, the policy advocates the adaptation of the integrated curriculum, where societal issues are prioritised and form part of the content to be addressed. Nevertheless, in the same breath, although passively addressed, the policy also suggests that academic standards be adhered to in order to equip learners with critiquing skills and to position them in the global world, where they would be part of globalisation. In this way, both horizontal and vertical curricula, as conceived by Stenhouse ${ }^{30}$ and Tyler ${ }^{33}$, respectively, are recommended. A blend of these curricula breeds what Montouri $^{34}$ terms Creative Inquiry, where learners acquire the opportunity to build their school of thought through self-inquiry and the accumulation of facts through proven research. The attempt to use both curricula, however, might prove problematic during the development process as developers, using their discretion, might favour one over the other, and thus diverting risk from addressing educational goals.

\section{Category 4: Educator roles}

Educators, as curriculum designers, act as a bridge between policy and practice. ${ }^{35}$ It would thus seem befitting for the policy framework to clearly outline the role(s) of the educator in ensuring a smooth transition from policy to effective enactment of the curriculum. However, the policy makes no mention of educator role(s), at least not elaborately. What is inferred in the policy is that educators play the role of a facilitator. 'Therefore, the new trend should move from teaching to facilitating learning', (p. 15). ${ }^{6}$ The quotation implies that the educator assumes the role of facilitating knowledge construction and an active learning process to address learner's needs. ${ }^{36}$ Thus, there is social representation in terms of a role to be undertaken by the educator as learner's needs are taken into consideration by helping them find their voice in order to situate themselves as independent individuals in a society. The guide to CASS document, which is a supplementary document to the policy, mentions the educator as a facilitator, albeit at the assessment level, as an agent for assessment of learning. ${ }^{24}$ This assertion suggests that educators are not only required to be facilitators of knowledge construction but also of assessment to establish what learners still need to acquire, and thus provide appropriate tools to aid with that process.

Therefore, it stands to reason that the policy should clearly outline the role of educators as interpreters and designers of learning programmes and the competencies embedded within this role, whilst taking into consideration different teaching and learning contexts. ${ }^{37}$ In this way, discrepancies between policy and practice may be significantly reduced. This could be carried out by minimising the absolute freedom of educators in interpreting the policy through the provision of flexible guidelines that can be bent to accommodate personal experiences and to address a prevailing context. Consequently, educators as designers of the curriculum could still engage their personal and unique interpretations (habitual representation) of the policy as influenced by their experience(s) with the environment. In this capacity, educators are allowed to design a curriculum that allows them to have a say in how learners should learn, as influenced by their unique context(s), as recommended by Stenhouse. ${ }^{30}$ However, such individual interpretations by educators, to a certain extent, should be guided by pointers, which would help prevent educators from misconstruing the policy.

The CAP also covertly entrusts educators with the role of subject specialist. This is deducted from the listed core subjects that contribute to the formation of learning areas in the policy document. ${ }^{6}$ Inciting an example from the policy, the core contributing subjects for the linguistic and literary learning area are Sesotho, English, Arts and Crafts, Drama, Music and other languages, which may include French, German and Spanish. ${ }^{6}$ From the mentioned subjects, it suffices that specialists are needed to provide in-depth knowledge of these disciplines. This suggests that educators should have content knowledge, which enlists their theoretical and conceptual knowledge of the discipline in question. ${ }^{38}$ This knowledge is informed by facts and schooled knowledge. However, the role of an educator as a subject specialist has not been presented as an apparent entity in the policy. This poses a threat to this role, which is overlooked by not only curriculum developers, but also educators who are expected to expertly execute it. ${ }^{39}$ This role should be clearly outlined because of its pedagogical implications addressed in the policy. ${ }^{40}$ This would help educators to execute their role of imparting knowledge effectively, whilst still allowing room for learners to be independent thinkers and to construct knowledge that is befitting to their personal, societal and professional growth.

\section{Category 5: Goals}

According to Raselimo and Mahao, ${ }^{3}$ education policy has a bearing on curriculum, pedagogy and assessment. Also, the 
authors state that education policy presents what should essentially be covered in schools. It is befitting, then, to discuss goals that have been outlined in the policy document as they depict aims, objectives and outcomes that should be attained through interaction with the curriculum. ${ }^{41}$ Aims are general statements that outline long-term intentions of teaching/learning. ${ }^{12}$ In other words, aims outline a general idea of what learners ought to be able to do at the end of a specified learning period, which is normally long term. In this instance, aims are written from the policymakers' point of view to highlight and indicate knowledge to be covered. The policy presents both aims and curriculum aims. ${ }^{6}$

Aims, as presented in the Lesotho policy statement, outline general knowledge that is expected to be acquired through the learners' acquaintance with education. The defined aims include ${ }^{6}$ :

... equipping learners with attitudes and skills which enable them to respond to socio-economic and technological challenges and 'providing opportunities for learners to participate in activities promoting democratic principles, human rights and emerging issues in a society'. (p. 12)

These aims provide curriculum developers/designers with a blueprint of what a curriculum needs to cover. ${ }^{42}$ This suggests that the outlined aims highlight a vague guide of what educators need to cover during practise. This thus leaves room for multiple personal interpretations of these aims, which might distort the overall idea of curriculum intentions. As aims are supposed to outline what has to be covered based on the intentions of the policy, ${ }^{41}$ aims provided in the policy must be clear and unambiguous to avoid misinterpretations.

The cited scholars' assertion is applicable to curriculum aims, which, at close inspection, seem to outline objectives. One curriculum aim is that: 'at the end of Secondary Education, students should apply acquired knowledge, skills, and attitudes necessary for effective participation in democratic processes and social activities' (p. 13). ${ }^{6}$ Objectives, as posited by Kennedy et al. ${ }^{41}$ provide specific statements of educational intentions, and the latter quotation seems to outline such intentions. Consistent is Khoza's ${ }^{43}$ assertion that objectives represent specific aims. The policy statement, thus, seems lacking in establishing a clear distinction between aims and curriculum aims. This omission leads to the wrong allusion that aims and curriculum aims are synonymous. Clarity could be achieved by altering the wording, that is, replacing curriculum aims with more accurate curriculum objectives. Objectives then would be understood as a means of reaching aims, although disparate from aims, as they are more specific and relatively short term. ${ }^{44}$ In this way, curriculum developers would be able to differentiate between the two concepts and use aims to inform objectives that would guide the effective enactment of the curriculum. Tyler ${ }^{33}$ is insistent on the fact that a clear outline of objectives is paramount in ensuring that educational purposes are accomplished. Also, Tyler posited that clearly outlined objectives provide knowledge, skills, attitudes and values that aid learners to deal with life problems. Objectives, termed as curriculum aims in the policy framework have been framed in a way that adheres to Tyler's latter assertion. This is because they outline what learners should ideally have acquired after a specified time.

The policy makes no mention of learning outcomes but does outline competencies, which are, to some extent, alluded to as outcomes. This brings to the surface yet another discrepancy in the policy statement in the sense that the policy advocates active participation of learners through the use of problem-centred activities. The omission of learning outcomes in the policy might be problematic as, according to Moon ${ }^{45}$, effective learning takes place when learners are exposed to a clear outline of what they are expected to achieve at the end of a prescribed period. Therefore, the exclusion of outcomes in a policy document is contradictory to the type of curriculum recommended in the policy, which is an integrated curriculum. Essentially, an objectives-oriented policy risks the passive participation of learners and seems to encourage educator-centred activities in place of problem-centred activities. In remaining faithful to and consistent with the concept of the integrated curriculum and what it stands for, the policy should include learning outcomes that would serve as guidelines for curriculum developers and designers, and at a later stage, learners. ${ }^{46}$

\section{Category 6: Resources}

Resources are divided into hardware, software and ideological ware. ${ }^{47}$ Khoza $^{16}$ posited that hardware is any tangible resource or tool that helps the process of teaching and learning in education. This may include chalkboards, computers and textbooks. Software resources, according to $\mathrm{Khoza}^{48}$, are materials/tools that are produced for the hardware in view of displaying information during the teaching and learning process. Software resources, such as PowerPoint, can be seen, but cannot necessarily be touched unless when printed. Ideological-ware resources are cognitive processes that manage learner actions in view of effectively using technology for learning and research. ${ }^{49}$ In other words, these resources drive any lesson in education as learning is about ideology and not necessarily about technology. ${ }^{48}$ However, these resources are not addressed in the policy. This omission presents both positive and negative implications. The positive implication is that curriculum developers and designers are free to select the resources that they deem appropriate and relevant in contributing to the attainment of goals. ${ }^{48}$ This then suggests that educators have a say in the selection of resources that would ultimately aid in the learning process. Nevertheless, as the selection of resources is reliant on goals to be achieved, ${ }^{41}$ misinterpretation of goals by educators might lead to a selection of irrelevant resources, thus further jeopardising 
the attainment of goals. Ideally, the policy should provide pointers regarding which resources would best help in the achievement of set goals. This affords developers a guideline, albeit not a rigid one, in selecting resources that would allow for an effective learning environment. This is especially resonant with ideological-ware resources, which provide the basis of learning in the sense that they influence teaching/learning goals. ${ }^{48}$ Ideological-ware resources are especially vital because they help to determine relevant hardware and software resources. Immaterial of their nature, resources have been identified as crucial in curriculum implementation and learner performance by many educators in South Africa and across the globe. ${ }^{5}$

\section{Category 7: Accessibility}

In terms of accessibility, the policy takes note of the Constitution of Lesotho and its stance on the essentiality to avail education to all people of Lesotho, regardless of their physical and social bearing, with one clause stating, 'a child who is physically and mentally handicapped is given the special treatment, education and care required by his/her condition' (p. i). ${ }^{6}$ In other words, the policy is cognisant of the vitality of provision of education to every child, irrespective of their physical or mental condition. ${ }^{50}$ This implies that no child should be denied access to education.

Physical access has been addressed in the policy as it considers the fact that there are learners who are not able to physically access education. The policy recommends that such learners receive special treatment and be granted access to the learning environment. In Mpungose' $\mathrm{s}^{51}$ view, this surmises that physical infrastructure should not impede access to education. In other words, if there are physically people with disabilities, it should be ensured that appropriate infrastructure is made accessible to them. In this way, the needs of each learner are taken into consideration in order to allow knowledge construction to take place. $^{52}$ The policy seemingly recommends making education physically accessible to all and insists on curriculum developers taking into consideration learners' interests.

In addition to physical access, the policy equally promotes financial accessibility relating to education. This is evidenced in the declaration that one of the reasons the policy was reformed was to accommodate 'new developments, including the free primary education strategy, which require policy re-articulation and refinement' (p. v). ${ }^{6}$ This assertion demonstrates efforts by the MOET to make education financially accessible and equitable, at least at the basic education level, to learners with different financial backgrounds. ${ }^{53}$ According to the $\mathrm{MOET}^{6}$, the free primary education policy was enacted in most of Lesotho primary schools in 2000. It is noteworthy to mention that primary education in Lesotho accounts for the first 7 years of learners' formal education.
In line with this initiative by the government to render education financially accessible, Morojele ${ }^{54}$ found that a lack of infrastructure and insufficient teaching resources were some of the impediments that were compromising effective implementation of the policy. This was mainly because of the influx of learners into schools as enticed by the notion of free primary education. However, despite the presence of free primary education policy, society is still partially responsible for ensuring that learners have financial access. As Lerotholi $^{55}$ claimed, parents and community members are still largely responsible for financially supporting education. The situation is motivated by the fact that free primary education is only applicable in government-supported schools. This indicates that learners whose parents have financial capacity are more advantaged to access quality education, where the educator-learner ratio is within educational standards, as compared with those who hail from financially disadvantaged families. In addition, at post-primary level, the community is completely responsible for financially supporting learners to ensure the continuation of studies. This suggests that financially disadvantaged learners may struggle to access education.

\section{Category 8: Location and time}

Location and time are viewed as different concepts in the curricular spider web by Van den Akker. ${ }^{9}$ However, for this article, they are merged and treated as one concept as they greatly influence each other. Location in education is a knowledge-based environment, where teaching and learning take place. ${ }^{56}$ Time as a curricular spider-web concept is concerned with 'when' educators are teaching. ${ }^{9}$ According to Van den Akker et al., ${ }^{13}$ allocation of time is essential to determine how much time can be spent on specific learning tasks. This assertion echoes that of $\mathrm{Khoza}^{48}$, who proclaimed that time is essential, especially when it comes to traditional face-to-face instruction. This is because educators need to adhere to the allocated time for efficient enactment of the curriculum. The policy framework neglects to mention the location and time in which education is expected to take place. For instance, is the learning environment supposed to be a traditional face-to-face instruction, online learning or a combination of both (blended learning)? Although Information and Communications Technology (ICT) is vaguely mentioned under the scientific and technological learning area, it remains uncertain if this would be carried out theoretically or practically. The policy should thus be vocal in terms of the teaching environment within which educators and learners are expected to function. This also applies to the concept of time, which should be specified to give educators a rough idea regarding how much time can be spent on specific learning tasks. ${ }^{50}$ In addition, the policy fails to indicate how much time may be allocated for each learning area, and this may result in discrepancies in different schools, where one learning area may be allocated more time in one school than the other. 


\section{Conclusion}

As declared by Van den Akker et al.,15 utilisation and alignment of curriculum concepts guarantee an effective teaching and learning environment. Seemingly although, the Lesotho policy statement neglects to address some curriculum concepts, as demonstrated here. This seems to suggest that curriculum developers and designers who continuously refer to and are faithful to the policy framework for the provision of pointers might be neglecting some curriculum concepts during the development of the curriculum. This might compromise the attainment of educational goals. Van den $\mathrm{Akker}^{57}$ further attested that policy reform is especially difficult on educators, who are tasked with its enactment, as they are usually 'poorly informed about an intended innovation' (p. 178). This implies that the policy should be clear and concise in order to facilitate its successful enactment. It is for this reason that this article recommends a revision of the current policy framework in view of including the curricular spider-web concepts in order to facilitate the effective curriculum development/design process.

\section{Acknowledgements Competing interests}

The authors declare that they have no financial or personal relationships that may have inappropriately influenced them in writing this research article.

\section{Authors' contributions}

The work presented in this article was developed from the doctoral study undertaken by M.A.M. at the University of KwaZulu-Natal.

\section{Funding information}

This research received no specific grant from any funding agency in the public, commercial or not-for-profit sectors.

\section{Data availability}

The authors confirm that the data supporting the findings of this study are available within the article.

\section{Disclaimer}

The views and opinions expressed in this article are those of the authors and do not necessarily reflect the official policy or position of any affiliated agency of the authors.

\section{References}

1. Government of Lesotho. Lesotho vision 2020 document. Maseru: GOL; 2000

2. Makumane $M, N g c o b o S$. The socio-economic value of French: The learners' voice S Af J Af Lang. 2018;38(2):56-69. https://doi.org/10.1080/02572117.2018.1463705

3. Raselimo $M$, Mahao $M$. The Lesotho curriculum and assessment policy: Opportunities and threats. S Afr J Educ. 2015;35(1):1-12. https://doi.org/ 10.15700/201503070025

4. Spaull N. Priorities for education reform (Background note for Minister of Finance 19/01/2019) [homepage on the Internet]. 2019 [cited 2019 Mar 13] Fvailable from: https://nicspaull.com/2019/01/19/priorities-for-educationreform-background-note-for-minister-of-finance-19-01-2019/
5. Molapo MR, Pillay V. Politicising curriculum implementation: The case of primary schools. S Afr J Educ. 2018;38(1):1-9. https://doi.org/10.15700/saje.v38n1a1428

6. Ministry of Education and Training. Curriculum and assessment policy education for individual and social development. Maseru: Ministry of Education and Training; 2009.

7. Makumane MA. Secondary school educators' enactment strategies of the French integrated curriculum content. Eur J Foreign Lang Teach. 2020;5(1):150-164.

8. Brasof M, Mansfield KC. Student voice and school leadership: Introduction. J Ethical Educ Leader J [serial online]. 2018[cited 2019 Mar 17];1:5-8. Available from: https://www.researchgate.net/publication/324136671_Student_Voice_ and_School_Leadership_Introduction

9. Van den Akker J. Curriculum perspectives: An introduction. In Van den Akker J, Kuiper W, Hameyer U, editors. Curriculum landscapes and trends. Dordrecht: Kluwer Academic Publishers, 2003; p. 1-10

10. Hall J. An integrated law curriculum: Balancing learning experiences to achieve a range of learning outcomes. J Int Comp Law. 2018;5(1):71-109.

11. Ngwenya J, Arek-Bawa O. Exploring the quality of grade 12 accounting education textbooks. J Transdisciplinary Res South Af. 2019;15(1):a662. https://doi.org/ 10.4102/td.v15i1.662

12. Hoadley U, Jansen J. Curriculum: Organising knowledge for the classroom. 3rd edn. Cape Town: Oxford University Press Southern Africa (Pty) Ltd; 2013.

13. Van den Akker J, Fasoglio D, Mulder H. A curriculum perspective on plurilingual education. Enschede: Council of Europe; 2010.

14. Berkvens J, Van den Akker J, Brugman M. Edited by addressing the quality challenge: Reflections on the post-2015 UNESCO Education Agenda. Paris: Netherlands National Commission for UNESCO; 2014.

15. Van den Akker J, De Boer W, Folmer E, et al. Curriculum in development. Enschede: Netherlands Institute for Curriculum Development (Slo); 2009.

16. Khoza SB. Using curricular spider-web to explore a research facilitator's and students' experiences. S Afr J High Educ. 2015;29(2):122-143. https://doi.org/ 10.20853/29-2-471

17. Mpungose CB. Teachers' reflections of the teaching of Grade 12 physical sciences CAPS in rural schools at Ceza Circuit [MEd thesis]. Durban: University of KwaZuluNatal; 2015

18. Schiro MS. Curriculum theory: Conflicting visions and enduring concerns. 2nd ed. Thousand Oaks, CA: Sage; 2013.

19. Elo S, Kyngäs $\mathrm{H}$. The qualitative content analysis process. J Adv Nurs. 2008; 62(1):107-115. https://doi.org/10.1111/j.1365-2648.2007.04569.x

20. Neundorf K. The content analysis guidebook. Thousand Oaks, CA: Sage; 2002.

21. Punch KF. Introduction to research methods in education. Thousand Oaks, CA; Sage; 2009.

22. Strydom H, Delport CSL. Information collection: Document study and secondary analysis. In A.S. De Vos, H. Strydom, C.B. Fouché, C.S.L. Delport, editors, Research at grass roots: For the social sciences and human service professions. 2nd ed. Pretoria: Van Schaik, 2002; p. 321-332.

23. Samuel M. On becoming a teacher: Life history research and the force field mode of teacher development. In: Dhunpath R, Samuel M, editors. Life history research: Epistemology, methodology and representation. Rotterdam: Sense Publishers, 2009; p. 3-18.

24. Examinations Council of Lesotho. Guide to continuous assessment: Implementing the curriculum and assessment policy and improving learning and achievement in Lesotho. Maseru: MOET; 2012.

25. Brown KL. From teacher-centered to learner-centered curriculum: Improving learning in diverse classrooms. Education. 2003;124(1):49-54.

26. Watson S, Miller T. LGBT oppression. Multicult Educ [serial online]. 2012 [cited 2018 Apr 10];19(4):2-7. Available from: https://files.eric.ed.gov/fulltext/ EJ1014937.pdf

27. Moloi KC. Learners and educators as agents of social transformation in dysfunctional South African schools. S Afr J Educ. 2019;39(1):a1800. https://doi. org/10.15700/saje.v39ns1a1800

28. Sharma GR, Ahmad MS, Batala LK, Ace BN. Policy paradox between local and national agencies of education: A lived experiences from local curriculum development practices in Nepal. Int J Educ Res. 2019;7(3):159-170.

29. Cross M, Mungadi R, Rouhani S. From policy to practice: Curriculum reform in South African education. Comp Educ. 2002;38(2):171-187. https://doi.org/ 10.1080/03050060220140566

30. Stenhouse L. An introduction to curriculum research and development. London: Heinemann; 1975.

31. Nembhard D. 'So why are we learning this?' Curriculum writing as professional development. In: Edstrom BM, Renwick K, editors. Proceedings of the Canadian Symposium XV Issues and Directions for Home Economics/Family Studies/Human Ecology Education; 2019 Feb 22-24; Vancouver: University of British Columbia; 2019, p. 102-106.

32. Bernstein B. Vertical and horizontal discourse: An essay. Br J Sociol Educ 1999;20(2):157-173. https://doi.org/10.1080/01425699995380

33. Tyler RW. Basic principles of curriculum and instruction. Chicago, IL: University of Chicago Press; 1949.

34. Montouri A. The quest for a new education: From oppositional identities to creative inquiry. ReVision. 2006;28(3):3-20. https://doi.org/10.3200/REVN.28.3.4-20

35. Samuel M. Accountability to whom? For what? Teacher identity and the force field model of teacher development. Perspect Educ. 2008;26(2):3-16. 
36. Jansen JD. Image-ining teachers: Policy images and teacher identity in South African classrooms. S Afr J Educ. 2001;21(4):242-246.

37. Shaikh ZA, Khoja SA. Role of teacher in personal learning environments. Digit Educ Rev. 2012;21(2):23-32.

38. Son J, Senk S. How reform curricular in the USA and Korea present multiplication and division of fractions. Educ Stud Math. 2010;74(2):117-142. https://doi. org/10.1007/s10649-010-9229-6

39. Modipane M, Themane M. Teachers' social capital as a resource for curriculum development: Lessons learnt in the implementation of a child-friendly schools programme. S Af J Educ. 2014;34(4):1-8. https://doi.org/10.15700/201412052105

40. Taole MJ. Teachers' conceptions of the curriculum review process. Int J Educ Sci. 2013;5(1):39-46. https://doi.org/10.1080/09751122.2013.11890059

41. Kennedy D, Hyland A, Ryan N. 2006. Writing and using learning outcomes: A practical guide. Bologna: European Higher Education (EHEA).

42. Harden RM. Curriculum planning and development: A practical guide for medical teachers. Edinburgh: Elsevier Churchill Livingstone; 2005.

43. Khoza SB. Is teaching without understanding curriculum visions and goals a high risk? S Afr J High Educ. 2016;30(5):1-16. https://doi.org/10.20853/30-5-595

44. Marken J, Morrison G. Objectives over time: A look at four decades of objectives in the educational research literature. Contemp Educ Technol. 2013;4(1):1-14. https://doi.org/10.30935/cedtech/6088

45. Moon J. The module and programme development handbook. London: Kogan Page Limited; 2002.

46. Khoza SB. Learning outcomes as understood by 'publishing research' facilitators at a South African University. Mevlana Int J Educ. 2013;3:1-11. https://doi.org/ 10.13054/mije.13.09.3.2

47. Yang SH. Using blogs to enhance critical and community of practice. Educ Technol Soc. $2009 ; 12(2): 11-21$.
48. Khoza SB. Who helps an online facilitator to learn with students in a day. Mevlana Int J Educ. 2012;2(2):75-84.

49. Amory A. Education technology and hidden ideological contradictions. Educ Technol Soc. 2010;13(1):69-79.

50. The United Nations Educational, Scientific and Cultural Organization (UNESCO). Guidelines for inclusion: Ensuring access to education for all. Paris: United Nations Educational, Scientific and Cultural Organization; 2005.

51. Mpungose CB. Rationale of teaching physical sciences curriculum and assessment policy statement content: Teachers' reflections. Int J Educ Sci. 2016;14(3): 256-264. https://doi.org/10.1080/09751122.2016.11890500

52. Raselimo M, Wilmot D. Geography teachers' interpretation of a curriculum reform initiative: The case of the Lesotho Environmental Education Support Project (LEESP). S Afr J Educ. 2013;33(1):1-15. https://doi.org/10.15700/saje. v33n1a681

53. Lekhetho $M$. The impact of free primary education on access and quality of primary education in Lesotho. Int J Educ Sci. 2013;5(4):397-405. https://doi.org/ 10.31901/24566322.2013/05.04.06

54. Morojele P. Implementing free primary education in Lesotho: Issues and challenges. J Soc Sci. 2012;32(1):37-45. https://doi.org/10.1080/09718923.2012. 11893050

55. Lerotholi LM. Tuition fees in primary and secondary education in Lesotho: The levels and implications for access, equity and efficiency. Paris: International Institute for Educational Planning/UNESCO; 2001.

56. Johnson WL, Rickel JW, Lester J. Animated pedagogical agents: Face-to-face interaction in interactive learning environments. Int J Artif Intell Educ. 2000; 11:47-78.

57. Van den Akker J. Building bridges: How research may improve curriculum policies and classroom practices. Sint-Katelijne-Waver: CIDREE; 2010. 